\title{
The Euro Zone Financial Meltdown and Sub-Saharan Africa's Financial Sector: Analysis and The Way Forward for Financial Development and Economic Growth
}

\author{
Ashford C. Chea, Ph.D. (Corresponendence Author) \\ Benedict College \\ School of Business and Economics \\ 1600 Harden Street, Columbia, SC 29204 USA \\ E-mail: Ashford.chea@yahoo.com
}

Received: December 10, 2015

doi:10.5296/ijrd.v3i1.8925
Accepted: January 15, 2016 Published: January 23, 2016

URL: http://dx.doi.org/10.5296/ijrd.v3i1.8925

\begin{abstract}
The purpose of the paper was to assess the effects of the euro zone financial crisis on sub-Saharan Africa's (SSA) financial sector. The evidence showed that the euro zone crisis had limited negative effects on SSA financial sector as a whole. However, individual countries were impacted negatively based on their relative integration into the global financial system and the idiosyncratic responses by policy makers to the crisis. The article begins with a historical perspective and underpinning of the euro zone financial crisis. Next, it presents a brief overview of the euro zone financial sector. This is followed by an analysis of SSA's financial sector and its exposure to the euro zone crisis. The paper then continues with a discussion of the transmission mechanisms of the crisis to SSA's financial sector. The article ends with an outline of policy lessons learned from the euro debt crisis, policy implications for SSA's financial sector, and recommendations for the way forward for financial development and stability in SSA.
\end{abstract}

Keywords: Euro Zone, Financial crisis, Sub-Saharan Africa, Financial sector, Financial development

\section{Introduction}

The euro zone debt crisis dates back to November 2009 when Greece experienced unprecedented levels of budget deficit reaching 15.5 percent of its GDP, a figure more than 
double what the country previously declared. Other countries that were plagued with the same symptom included Ireland, Portugal, and Spain where the budget deficit ratio to GDP reached 14.2 percent, 10.2 percent, and 11.2 percent respectively. In fact, the year 2009 represented a turning point in the life of the euro zone. All euro zone countries in this year experienced negative growth rates on their GDP ranging from minimum decline of 3 percent to a maximum of 14 percent. Moreover, sovereign debt ratios to GDP exceeded the 100 percent in Greece and Italy and 70 percent in other countries such as Austria, Belgium, France, Germany, and Portugal (IMF. 2012).

Table 1. Budget deficit and public debt ratios as percentage of GDP for selected Eurozone countries

\begin{tabular}{llll}
\hline Country & Budget Deficit as \% of GDP & Public Debt Ratio as \% of GDP & Date \\
\hline Greece & 15.5 percent & Over 100 percent & November 2009 \\
Ireland & 14.2 percent & $\mathrm{n} / \mathrm{a}$ & November 2009 \\
Spain & 11.2 percent & $\mathrm{n} / \mathrm{a}$ & November 2009 \\
Portugal & 10.2 percent & 70 percent & November 2009 \\
\hline
\end{tabular}

Adding to the pressure on the European Central Bank and the euro zone the global economy has been looking shakier latterly. Both United States and China experienced manufacturing slowdowns in January. Japan's economy grew a less-than-expected 1 percent year-over-year in the fourth quarter, and emerging market assets have endured a major selloff in the last two months (Kindergen, 2014). Moreover, the global outlook for 2014 and beyond is dampened by long-term constraints as well. Indeed, there is a looming risk of secular stagnation in many economies, owing to the adverse effect on productivity growth of years of underinvestment in human and physical capital. And the structural reforms that these economies need to boost their potential growth will be implemented too slowly. While the euro zone tail risks are lower, its fundamental problems remain unresolved: low potential growth, high unemployment; still-high and rising levels of public debt, loss of competitiveness and slow reduction in unit labor costs; and extremely tight credit rationing, owing to banks' ongoing deleveraging (Roubini, 2014).

\subsection{Objectives of the Paper}

The objectives of the paper were to analyze the following: (1) SSA Financial Sector and its exposure to the euro zone financial crisis; (2) The channels of transmission of euro zone financial crisis to SSA financial economy; (3) The impact of the euro zone crisis on capital flows to SSA financial sector (4) policy lessons, implications, and recommendation for the way forward for long-term financial stability, financial development, and economic growth.

\section{Research Method}

This paper relied on the literature review of current relevant article focusing on the euro zone debt crisis and its effects on SSA financial economy in particular. Except where a source was 
needed specifically for its perspective on broad issues pertinent to euro zone financial meltdown and SSA, the author screened papers by "euro zone financial crisis and SSA financial sector" and by numerous variant of keywords, focusing particularly on SSA financial economy. Source papers included refereed research studies, empirical reports, and articles from professional journals. Since the literature relating to the euro zone financial crisis is voluminous, the author used several decision rules in choosing articles. First, because global financial forces are changing fast in today's environment, the author used mostly sources published from 2009-2014, except where articles were needed for their historical perspectives. Second, given the author's aim to provide a practical understanding of the main issues underpinning the euro zone financial crisis and SSA financial sector, he included, in order or priority: refereed empirical research papers, reports, and other relevant literatures on current trends in the euro zone area and capital flows to SSA. The resulting materials included a large quantity of journal articles, empirical reports, and professional documents. Both a thematic and structured approaches were used to examine, separate and choose which sources to review and include in this article. All materials were then grouped by key words such as euro zone, financial crisis, impact, SSA financial sector, growth, and development for the purpose of analysis. As a result, all of the referenced sources provided the required information from which outcomes (i.e. evidences and conclusions) were derived. To get some perspective on the roots causes and current state of the euro zone financial crisis and its impact on SSA, the author began with the review of the current literature.

\section{The Euro Zone Financial Sector: A Brief Background}

The euro zone financial system has undergone a massive transformation since the late $1990 \mathrm{~s}$, via deregulation and innovation. For example, derivatives rose from $2 \frac{1}{2}$ times world GDP in 1998 to a quite staggering 12 times GDP on the eve of the crisis, while primary securities remained broadly stable at around 2-times GDP over this period. The divergent trends are indicative of the growth of "capital markets banking" and the re-hypothecation (repeated re-use) of the same collateral that multiplies counterparty risk through the banking system. Furthermore, Europe mixes traditional and capital markets banking, and this was interacting with the sovereign crisis in a dangerous way (Blundell-Wignall, 2012).

The banking sector and the inter-bank market - the banking sectors in the peripheral countries of the euro zone carried a large number of potentially bad assets on their balance sheets. Banks had stopped trusting each other leading to a fairly dysfunctional interbank market. The ECB had to step in to get the inter-bank market going again with two facilities. Initial indications were that the intervention had worked for some time. The markets reacted positively to this. Liquidity condition in the inter-bank market, declined from its highs in the last quarter of 2011. Portuguese banks increased their bank holding of euro area government debt by 4.24 billion euro, Greek banks by 4.12 billion euro while Italian banks increased their holding by 23 billion euro in February. It took some time before these liquidity injections started to flow to the real sector (Kganyago, 2012). 


\section{SSA Financial Sector: Obstacles to Efficiency and Exposure to Euro Zone Crisis}

Vibrant financial markets play a critical role in channeling resources into productive investment and fostering growth. The main obstacles of efficient financial markets in many SSA countries include:

1. An inadequate regulatory framework which makes for a high concentrated banking sector, very low intermediation rates, and inefficient collateral registry systems that further impede businesses and individuals' access to credit.

2. A banking sector that fails to exercise its role of intermediation due to very high interest rate spreads which makes credit expensive. Moreover, deposits are poorly remunerated.

3. Underdeveloped capital markets that remain narrow and illiquid, thereby limiting access to long-term financing and hindering countries' capacities for local debt financing.

4. A lack of innovative financial instruments, notably those geared towards small and medium enterprises, which constitute a majority of the businesses on the continent but remain too often confined to the informal sector due to inadequate financial services (Dahou, Omar, and Pfister, 2009).

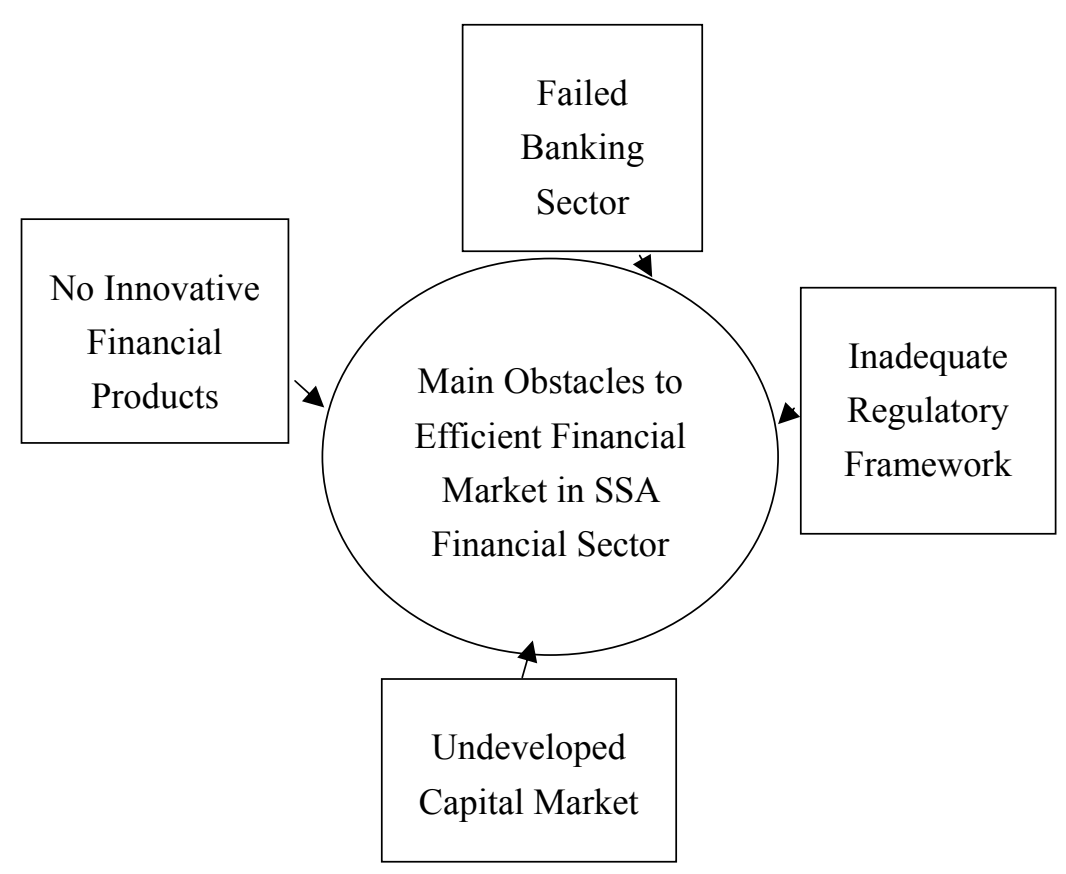

Figure 1. Main obstacles to efficient market in SSA financial sector

In terms of SSA financial sector venerability to the euro zone debt crisis, a first observation is that European banks have a sizable presence in SSA, largely reflecting historical linkages. On average, more than 90 percent of all SSA liabilities to Bank of International Settlement (BIS)-reporting banks are to European banks. European banks conduct cross-border transactions and manage subsidiaries, branches, and representative offices in many SSA countries. The importance of these subsidiaries is particularly large in some countries. For 
instances, subsidiaries of British financial institutions manage more than 30 percent of deposits in Botswana, Mauritius, South Africa, and Zambia, while affiliates of Portuguese banks manage about two-thirds of deposits in Angola (IMF Regional Economic Outlook, 2012).

Similarly, the more modern and globalized the banking system, the more it was affected. The banking system of South African and Nigeria were the most affected because they were most exposed to the outside world. The banks of these countries depended very much on short-term capital. The more dynamic an economy, the more it depended on short-term capital. In West Africa, Nigeria's banking system was the least immune. The country, not too long ago, completed a serious and courageous restructuring of its banking system at the urging of the central bank. Twenty-five small banks created five large groups better adapted to the size and dynamism of the national economy. Ghana was practically in the same position. The more dynamic an economy was, the more it was incorporated into globalization, the more it consumed short-term working capital and thus the more it was exposed to the crisis. Conversely, the countries in the Franc Zone were protected by their antiquated banking system. Their economies were much less banked than those of Ghana and Nigeria and the big Anglo-Saxon banks have little influence over their financial sectors. Moreover, the banks there deal in working capital, mostly in Central Africa (Zinsou, 2008)

East African banking systems are relatively small and the deepening of the sector has been largely driven by African not European, banks. On the other hand, South Africa's financial sector is globally integrated and is SSA's largest borrower from Europe. The outflow of portfolio capital in the second half of 2010, which put pressure on the rand, demonstrated this exposure. The other Southern African Customs Union members (Botswana, Lesotho, Namibia, and Swaziland) were also exposed through integration with South Africa' financial sector.

Their sovereign bond markets had also been affected. More frontier markets such as Kenya, Uganda, Tanzania, and Nigeria, which postponed the launch of sovereign bonds amid the global financial crisis, decided to postpone it further. Those that still planned to issue bonds, such as Ghana faced significant higher costs. The shock from such turmoil in global bond markets was concentrated in countries with weak fiscal balances and high indebtedness such as Zimbabwe, DR Congo, and Guinea-Bissau with external debt of over 100 percent of GDP (The African Economist, 2012).

\section{Channels of Transmission of the Euro Zone Financial Crisis to SSA's Financial Sector}

The Contagion effect of the euro zone financial crisis on SSA financial sector depends on the extent of which SSA financial economies are integrated into the euro zone financial sector. The presence of euro zone banks is strong in some countries such as Mozambique, Madagascar, Botswana, Ghana, Cameroon, Rwanda, Zambia, and Tanzania, where these banks represent over half of total banking assets. All these countries were partly vulnerable to a tightening of credit markets that followed on the euro zone financial crisis (AfDB, 2012). However, despite the strong presence of European banks, most SSA's bank credit and 
funding availability was not directly affected. This is because residents' cross-border liabilities to European banks were a relatively small share of GDP for most of the region's countries, with a few exceptions. On an ultimate risk basis, these liabilities amounted to, on average, 5 percent of GDP in June 2011. Notable exceptions include Cape Verde, Gambia, Sao Tome and Principe, Sierra Leone, and Togo. For these countries reduced access to cross-border credit lines cut short funding (Regional Economic Outlook, 2012). That said, many individual country factors influence the speed and intensity with which financial shocks propagate across these economies. Financial linkages, such as common exposure by banks and mutual funds, play an important role in the transmission of common shocks and in financial contagion. It is also known that financial integration, the result of lower barriers to cross-border financial flows, generally facilitates the international propagation of financial shocks (Bekaert et al, 2013). However, countries that wish to benefit from financial globalization can reduce its unpleasant side effects by becoming more transparent. In other words, increasing transparency may be effective instrument for countries to consider before resorting to other measures aimed at reducing the adverse consequences of capital flows (Brandao-Marques, Gelos, and Melgar, 2013).

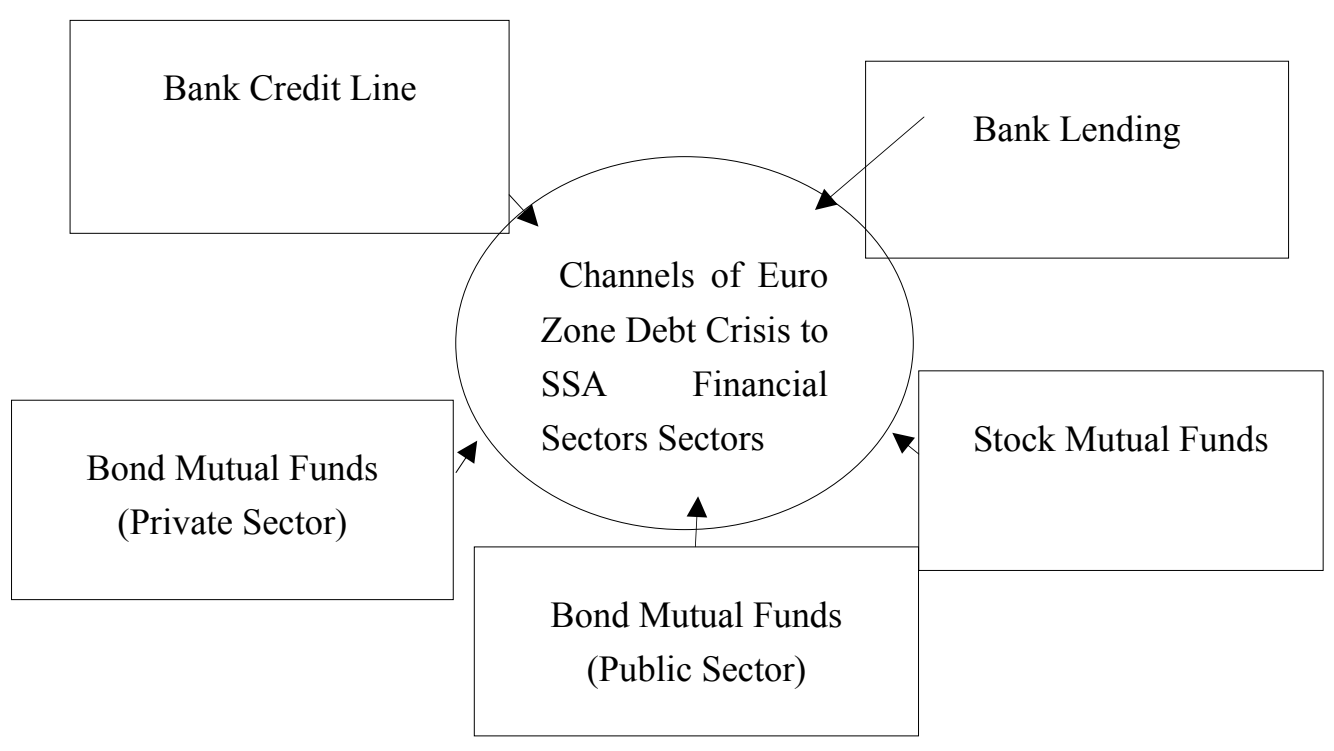

Figure 2. Channels of transmission of the Eurozone debt crisis to SSA financial sector

When it comes to SSA, bank soundness indicators were also adversely affected by deterioration in the external environment generally and the euro zone crisis specifically: first, global risk aversion affects SSA banks' liquidity and profitability. Second, as could be expected, lower exports prices decrease bank profitability and increase nonperforming loans, consistent with previous research findings (Flamini, McDonald, \& Schumacher, 2009; Hartelius, 2010). Third, surprisingly, slower credit growth was associated with declining nonperforming loans in SSA (Mendoza \& Torrones, 2008). International experience suggests that careful oversight is needed even when credit is growing from a very low base and when 
further financial deepening is warranted. The ability of SSA banking systems to withstand global financial stress, such as the euro zone debt crisis, depended on the strength of their capital buffers. As in many emerging countries, reported capital buffers in SSA were larger than those in advance economies. This partly reflected the fact that bank profitability largely depended on volatile macro-financial conditions. Volatility of bank profits may not be a concern if capital buffers are large enough to allow banks to absorb periodic losses (Regional Economic Outlook, 2012).

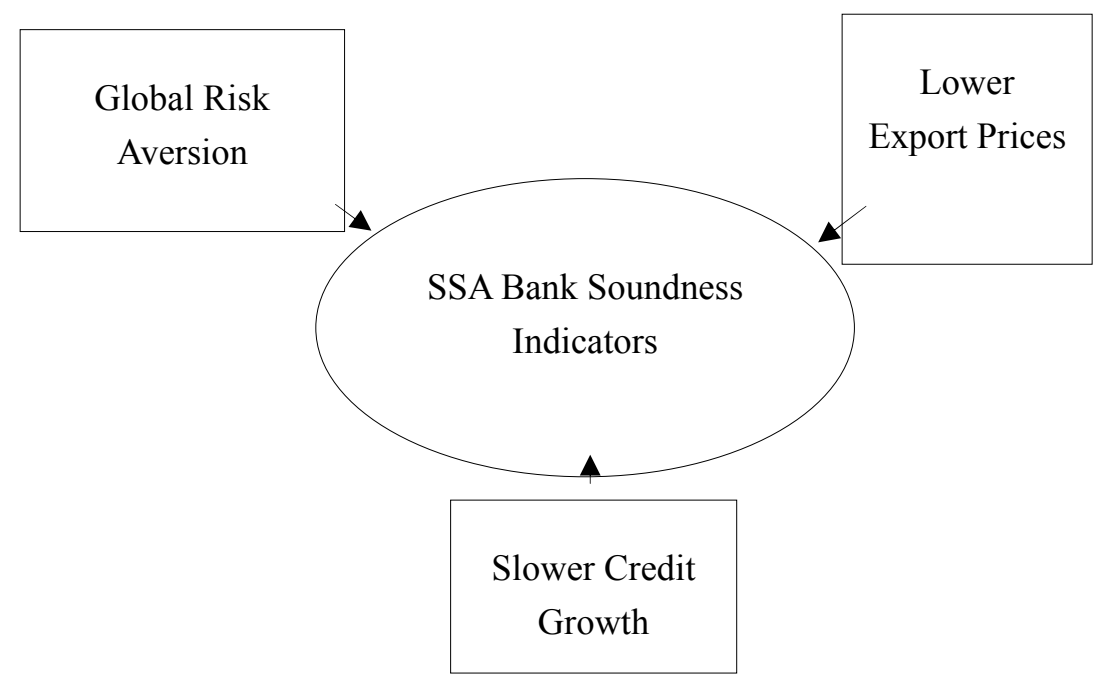

Figure 3. Factors Affecting SSA bank soundness from deterioration of Eurozone crisis

\section{Impact of the Euro Zone Crisis on Capital Flows to SSA's Financial Sector}

As the preceding analysis shows, the contagion effect of the euro zone debt crisis on SSA banking sector depended on the extent to which SSA banks were integrated into the European banking system. The presence of European banks was strong in some SSA countries, such as Mozambique, Madagascar, Botswana, Ghana, Cameroon, Rwanda, Zambia and Tanzania, where these banks represented over half of total bank assets. Angola, Uganda and several other countries also exhibited high levels of foreign banks' dominance. All these countries were particularly vulnerable to a tightening of credit markets that could follow on the euro zone debt crisis (AfDB Brief, 2012).

Other capital flows such as portfolio investments and government bond purchases may be pulled to these debt-ridden countries. In other words, there were an outflow of the capital investments made in SSA economies, with a particular impact on Egypt, Nigeria and South Africa. It is important to pay attention to these potential outflows as they led to liquidity constraints, especially in certain sectors relying on extractive resources (UNECA, 2012). Moreover, while it is still early to assess the full impact of the euro zone crisis on credit risk, available data suggests that the credit default swap increased 22.8 percent on South Africa bonds over the month ending August 30 2011. Similarly, spreads increased on sovereign bonds issued by frontier markets such as Ghana ( 2.23 percent), Nigeria (2.7 percent), and 
Senegal (1.2 percent) in the week ending September 2, 2011 (Bloomberg, 2011). Thus, a deepening of the crisis made it costlier for SSA governments to raise finance on international credit markets (AfDB Brief, 2012).

Table 2. Impact of Euro Zone crisis on SSA credit default swap for selected countries

\begin{tabular}{lll}
\hline Country & Increase in Credit Default Swap & Date \\
\hline South Africa & 22.8 percent & August 30, 2011 \\
Nigeria & 2.7 percent & September 2, 2011 \\
Ghana & 2.23 percent & September 2, 2011 \\
Senegal & 1.2 percent & September 2, 2011 \\
\hline
\end{tabular}

\section{Policy Lesson Learned from the Euro Zone Financial Crisis for SSA's Financial Economy}

There are several lessons to learn from the occurrence of recent financial crisis, particularly the sovereign debt crisis in Europe. One critical lesson is that the current international financial architecture cannot be left unchanged. Hence, there is a need to adopt prudent macroeconomic policies at the national level. Central banks, financial regulators and credit agencies including those in SSA should play a key role in establishing the new architecture, supported by governments passing the relevant legislations. Another lesson to be drawn from the crisis relates to the need for monitoring of countries with high proportion of short-term debt as well as private capital flows in their external liabilities. Countries including those in SSA should be required to provide data on their economies' overall level of external indebtedness, with an emphasis on the private component of debt, and give a breakdown of the debt by maturity and creditors. The sovereign debt default in the euro zone makes this lesson all the more important (UNECA, 2012).

Furthermore, three serious disorders relating to the euro zone crisis confront the short and medium term outlooks that could negatively affect the global finance and SSA financial sector: The first is the effects of macroeconomic policy making in advanced economies. These policy settings, intended to resolve the combination of slow growth and over indebtedness contributed to the flow of capital into SSA. The second disorder is the financial markets in advanced economies. High debt levels in the developed world and the European sovereign debt crisis have triggered unconventional policy responses and a variety of risks is evident. The third disorder was the possibility of financial contagion that would affect emerging market economies. In this instance, countries including SSA economies with financial vulnerabilities would experience local currency asset sales and capital flight (Kganyago, 2012). Additionally, from a practical standpoint, this means that SSA's financial sector liberalization and capital market opening need to be carefully managed. This is because a sudden surge of capital inflows can undermine previously protected domestic financial sectors. Thus, to minimize the risk and severity of crisis, SSA financial policymakers must first strengthen prudential regulations and allow vulnerable banking 
systems time to learn risk management techniques and restructure their balance sheets. Debt flows, especially short-term debt, tend to be more pro-cyclical and volatile and to magnify the negative impact of adverse shocks on financial sector and on economic growth (IMF Regional Economic Outlook, 2010).

\section{Policy Implications for SSA’s Financial Sector}

Banks in SSA have asset-side exposure to segments of the euro zone financial system that have come under stress, posing risk to banks' foreign assets. This development has the following policy implications, which should be adapted according to each economy's level of financial development and implementation capacity:

1. Country authorities need to move ahead with their plans to strengthen supervisory capacity and financial sector resilience. Close bank monitoring in countries experiencing fast credit growth is a priority;

2. The emerging of Pan-African banking groups creates the need for regional supervisory arrangements to ensure that these banks are subject to consolidated supervision. Effective mechanisms for limiting cross-border contagion - such as ring fencing arrangements aimed at preserving subsidiaries' resources — could be added to a review of existing banking-resolution framework;

3. Given financial stresses in Europe, supervisory authorities should undertake a review of commercial bank and central bank standards and practices in regard to the placement of foreign investment and deposits; and

4. Further actions are warranted to explore the impact of macroeconomic developments on systemic financial risk in SSA. International financial institutions can play a facilitating role in this regard, but enhanced dialogue between the relevant authorities in the region's largest financial systems would improve the evaluation of systemic risks (IMF Regional Economic Outlook, 2012).

\section{Policy Recommendation for SSA's Financial Sector for the Way Forward}

Policies for establishing well-functioning and inclusive financial markets in SSA's financial sector should take into consideration the following:

1. Address regulatory bottlenecks by putting in place and enforcing laws aimed at fostering confidence in investors and banks through the creation of credit bureaus that oversees repayment records.

2. Reorganize the banking system through opening the sector to competition, reviewing prudential ratios and putting in place innovative savings and borrowing instruments adapted to local needs.

3. Develop capital markets and particularly bond markets for long-term financing needs by setting up adequate guarantee schemes against currency and other type of risks. 
4. Bridge the gap between the informal and formal financial sectors by formalizing microfinance institutions to help them scale up activities while developing financial products geared towards small and medium enterprises. Innovative financial tools that use technology such as mobile banking can also help leapfrog traditional finance services and reach a larger population (Dahou, Omar, \& Pfister, 2009)

\section{Concluding Remarks}

SSA as a whole managed to largely avoid the euro zone financial contagion in their financial sector for the most part. It is time to salute the central bankers and regulators for ensuring well-capitalized, strongly regulated banks with the ability to continue financing their economies. The new banking regulations being proposed to strengthen the capital and liquidity positions of global banks have not impacted capital flows to low income countries as originally feared (Kaberuka, 2012). Even though SSA financial sectors were largely shielded from the impact of the crisis, direct government interventions in the banking sector were rare. Nigeria was the exception, where in August 2009 the central bank of Nigeria had to inject funds into the banking system, after five leading banks (40 percent of the banking sector) posted losses from non-performing loans due to excessive lending to the energy sector and the bursting of the stock market bubble. In Tanzania, the government set aside a part of the stimulus package for banks that have experienced rising non-performing loans (Brixiova, Kamara, \& Ndikumana, 2012).

However, from a longer-term perspective, especially given the budget woes of traditional donor, official financing is likely to continue declining in importance and competition for external private financing is likely to become more intense. Experience with in SSA suggests that the same sort of reforms needed to liberate productive potential — promoting trade and financial sector development, encouraging domestic savings and investment, raising standards of governance, and building up institutions - are also likely to help attract sustained private inflows (IMF Regional Economic Outlook, 2010). Financial sector supervision and regulation should now focus more strongly on macro-prudential supervision, including the need to systematically link overall financial sector balance sheets to fiscal and external sector accounts. Likewise, SSA central banks' supervisory and regulatory functions should be strengthened and there should be minimal government intervention in the decisions taken by the regulatory agencies. This will assist in the enforcement of the rules and regulations of prudent financial management among financial institutions. It should be accompanied by the strengthening of financial institutions and enforcement of strict transparency standards in financial transactions (UNECA, 2012).

In sum, SSA economies need to strengthen the domestic and regional basis for financial development and growth. This is best done by strengthening regional and extra-regional commercial agreements, strengthening macroeconomic policies, and developing financial institutions and human capital. Attracting FDI and making better and more use of imported technology and skills is also critical to long-term sustainable financial stability, financial development, and economic growth (Kganyago, 2012). 


\section{References}

AfDB Brief. (2012). The impact of the US credit rating downgrade and European debt crisis on Africa. African Development Bank: Tunis, Algeria.

Bloomberg. (2011). BRICS no cure for global economic growth. September 1.

Blundell-Wignall, A. (2012). Solving the financial and sovereign debt crisis in Europe. OECD Journal: Financial Market Trends, 2, 1-23.

Brixiova, Z., Kamara, A.B., and Ndikumana, L. (2012). Africa rebounding: When and how to exit from crisis intervention policies. The African Development Bank Group: Tunis, Algeria

Brixiova, Z., Kamara, A. B., \& Ndikumana, L. (2010). Containing the impact of the crisis and paving the way to strong recovery in Africa. AfDB Policy Brief No. 2. The African Development Group: Tunis, Algeria

Dahou, K., Omar, H. I., \& Pfister, M. (2009). Deepening African financial markets for growth and investment: Ministerial and Expert Roundtable of the NEPAD-OECD Background paper on Africa investment Initiative.

Flamini, V., McDonald, C., \& Schumacher, L. (2009). the determinants of commercial bank profitability in sub-Saharan Africa. IMF Working Paper 09/15 (Washington, D. C: IMF).

Hartelius, K. (2010). Analyzing nonperforming loans in Central and Eastern Europe based on historical experience in emerging markets. Global Financial Stability Report-April (Washington, D. C.: IMF).

Kaberuka, D. (2012). The global economy rebuilding resilience in SADC and Africa. Speech by AfDB president. Retrieved from http://www.afdb.org/news-and-events/article/the-global-economy-rebuilding-resilience-in-s

Kganyago, L. (2012). The impact of the Eurozone financial crisis on African economies. South African Reserve Bank: Pretoria, SA.

Kindergen, A. (2014). If QE came to Europe. The Financialist.

Mendoza, E. G and Marco, E.T. (2008). An anatomy of credit boom: Evidence from macro aggregates and micro data. NBER Working Paper 14049 (Massachusetts: National Bureau of Economic Research).

Regional Economic Outlook. (2012). Sub-Saharan Africa: Sustaining growth amid global uncertainty. Washington, D.C.: International Monetary Fund.

Regional Economic Outlook. (2010). Sub-Saharan Africa: Back to high growth? Washington, D.C.: International Monetary Fund.

Roubini, N. (2014). The global economy in 2014. Retrieved July 22, 2014 from http://www.social-europe.eu/2014/01/global_economy_2014

The African Economist. (2012). The impact of the euro zone crisis on Africa (pp. 1-6). 


\section{Macrothink}

International Journal of Regional Development ISSN 2373-9851 2016, Vol. 3, No. 1

UNECA (2012). The impact of the European debt crisis on Africa's Economy: A background paper (E/ECA/CM/45/3). Addis Ababa: ECA.

Zinsou, L. (2008). The impact of the international financial crisis on West Africa. Retrieved from http://www.oecd.org/swac/theimpactoftheinternationalfinancialcrisis

\section{Copyright Disclaimer}

Copyright for this article is retained by the author(s), with first publication rights granted to the journal.

This is an open-access article distributed under the terms and conditions of the Creative Commons Attribution license (http://creativecommons.org/licenses/by/3.0/). 